\title{
The construction of ecological and economical production function for energy dependent economics
}

\author{
Dyachok V.V., Gaiduchok O.V. \\ Lviv Polytechnic National University \\ 12 S. Bandera str., 79013, Lviv, Ukraine
}

(Received 20 May 2015)

\begin{abstract}
A system model of two-sector economics in which energy and production sectors act separately is described. Production is divided into two sectors - the first sector makes the final product, and the second sector - produces energy required for a final product. The models for the production sectors are written down. The system model as a system of differential equation is obtained. Based on the distribution of productive capacity according to the technologies, the parametric representation of ecological and economical production function is shown.
\end{abstract}

Keywords: system model of two-sector economics, ecological and economical modeling, ecological and economical production function.

2000 MSC: 93C23, 49K20

UDC: 519.86

The current stage of development of human civilization is characterized by increased attention to issue of environmental protection and rational use of natural resources. The complexity and diversity of this problem leads to mathematical modelling as an important tool to find the most effective measures of preventing the negative impact of industrial activity on nature. The development of environmentaleconomic modelling was caused by the actual needs of human society and growing role of ecology. The importance of this problem is recognized not only by scientists, but also society as a whole on a global level. This, as we know, formed the concept of sustainable development, the implementation of which is possible through the development of practical models of ecological and economic balance, including models of ecological and economic functions. As ecological and economic function we will understand the optimal issues (maximum or minimum) in terms of ecological and economic balance.

For research and forecasting future economic situation there are many methods, as the method of time series; methods for linear and nonlinear regression analysis by simulation; econometric models. However, analysis of existing models has found that they do not implement system approach [1-3]. Specificity of system approach of building a macroeconomic model is that this approach focuses on integrity of various types of complex object relationships and brings them into a single theoretical picture. First system economic model was built in the works of Petrov [4].

The aim of this article is to develop an approach of constructing the ecological and economical production function. This approach could be used for prediction of future scenarios of economics development for energy dependent economics.

Let's consider a closed economics, i.e. the economics without foreign exchange. All economic agents act on the perfect competition market. Prices for product and recourses are formed by the interaction of aggregate demand and supply of goods. We assume that such economics greatly depends on the supply of imported energy raw. Rising prices for energy raw leads to change in all macroeconomic indicators, including an increase in the price of goods. However, it is unknown how much the price of goods will increase at different modes of energy raw price changes.

Production is aggregated into two sectors. The first sector produces end product, part of which is used as a consumer product, and others part to create capacity in both sectors. The second sector 
processes an energy raw (oil, gas and coal), which is spent in the first sector while producing process, and for the final consumption of population $[5,6]$.

The production function of the first sector is represented by:

$$
Y_{1}=M_{1} f_{1}\left(x_{1}^{1}, x_{1}^{G}, x_{1}^{N}, x_{1}^{V}\right), \quad x_{1}^{1}=\frac{R^{L}}{M_{1}}, \quad x_{1}^{G}=\frac{E^{G}}{M_{1}}, \quad x_{1}^{N}=\frac{E^{N}}{M_{1}}, \quad x_{1}^{V}=\frac{E^{V}}{M_{1}},
$$

where $M_{1}$ is the power of the first sector, $f_{1}\left(x_{1}^{1}, x_{1}^{G}, x_{1}^{N}, x_{1}^{V}\right)$ is the production function of the first sector, $R^{L}$ is the amount of labour force, $E^{G}, E^{N}, E^{V}$ are the amounts of raw stuff of gas, oil, and coal, $x_{1}^{G}, x_{1}^{V}, x_{1}^{N}$ are the amounts of gas, coal, oil raw stuff per unit power involved for the production of the first sector. Demand functions for labour $R^{d}$, energy $E^{d}$ and function of product supply $Y_{1}^{*}$ are provided from the conditions of maximum current income producing product:

$$
\Pi_{1}\left(x_{1}^{1}, x_{1}^{1}, x_{1}^{G}, x_{1}^{N}, x_{1}^{V}\right)=M_{1}\left[p_{1} f_{1}\left(x_{1}^{1}, x_{1}^{G}, x_{1}^{N}, x_{1}^{V}\right)-s x_{1}^{1}-p_{2}^{G} x_{1}^{G}-p_{2}^{N} x_{1}^{N}-p_{2}^{V} x_{1}^{V}\right] \rightarrow \max _{x_{1}^{1}, x_{1}^{G}, x_{1}^{N}, x_{1}^{V}},
$$

which is equivalent to equations

$$
\begin{array}{ll}
\frac{\partial f_{1}\left(x_{1}^{1}, x_{1}^{G}, x_{1}^{V}, x_{1}^{N}\right)}{\partial x_{1}^{1}}=\frac{s}{p_{1}}, & \frac{\partial f_{1}\left(x_{1}^{1}, x_{1}^{G}, x_{1}^{V}, x_{1}^{N}\right)}{\partial x_{1}^{G}}=\frac{p_{2}^{G}}{p_{1}} \\
\frac{\partial f_{1}\left(x_{1}^{1}, x_{1}^{G}, x_{1}^{V}, x_{1}^{N}\right)}{\partial x_{1}^{V}}=\frac{p_{2}^{V}}{p_{1}}, & \frac{\partial f_{1}\left(x_{1}^{1}, x_{1}^{G}, x_{1}^{V}, x_{1}^{N}\right)}{\partial x_{1}^{N}}=\frac{p_{2}^{N}}{p_{1}}
\end{array}
$$

where $s$ is the salary wage, $p_{1}$ is the price of the first sector product, $p_{2}$ is the price of the second sector product (gas, oil, and coal respectively).

The total power changes could be written as

$$
\frac{d M_{1}}{d t}=I_{1}-\mu_{1} M_{1}
$$

where $I_{1}$ is the speed of creating new facilities.

The second sector is subdivided into three parts. The supply of raw material is represented by equations:

$$
Y_{2}^{G}=M_{2}^{G} f_{2}\left(x_{2}^{G}\right), \quad Y_{2}^{N}=M_{2}^{N} f_{2}\left(x_{2}^{N}\right), \quad Y_{2}^{V}=M_{2}^{V} f_{2}\left(x_{2}^{V}\right)
$$

here $M_{2}^{G}, M_{2}^{N}, M_{2}^{V}$ are gas / oil / coal processing power; $f_{2}\left(x_{2}^{G}\right), f_{2}\left(x_{2}^{N}\right), f_{2}\left(x_{2}^{V}\right)$ are production functions for gas, oil, and coal sectors, respectively; $V_{E}^{G}, V_{E}^{N}, V_{E}^{V}$ is the number of gas / oil / coal raw materials consumed; $x_{2}^{G}=\frac{V_{E}^{G}}{M_{2}^{G}}$ is the amount of raw gas per unit of power involved in processing gas; $x_{2}^{N}=\frac{V_{E}^{N}}{M_{2}^{N}}$ is the amount of raw oil per unit of power involved in the production of oil products; $x_{2}^{V}=\frac{V_{E}^{V}}{M_{2}^{V}}$ is the amount of raw coal per unit of power involved in coal processing.

The population is divided into two groups: workers and owners. Workers and owners consume the product first sector and energy (oil, gas and coal) in fixed proportions. Employee's income is only salary, it is spent on consumption.

Energy cannot be stored, so the price of energy varies depending on the supply and demand for it. Producers create a unified system of energy supply. So when demand is lower than supply, the price of energy decreases much more slowly than it increases when supply is less than demand.

Based of the above reasons (as well as the results of [6-8]) the closed system of functional differential equations for the power sector and capital markets and the prices of basic products sector wages, prices 
of gas, oil and coal is obtained (process is fully presented in the [8]):

$$
\begin{aligned}
& \frac{d M_{1}}{d t}=\left(\frac{k k_{1}}{p_{1} b_{1}} f_{1}\left(x_{1}^{1}, x_{1}^{G}, x_{1}^{N}, x_{1}^{V}\right)-\mu_{1}\right) M_{1}+\frac{k_{1}}{p_{1} b_{1}}\left(\mu_{1}^{*} K_{1}+\mu_{2, G}^{*} K_{2}^{G}+\mu_{2, N}^{*} K_{2}^{N}+\mu_{2, V}^{*} K_{2}^{v}\right) ; \\
& \frac{d M_{2}^{G}}{d t}=I_{2}^{G}-\mu_{2}^{G} M_{2}^{G} \\
& \frac{d M_{2}^{N}}{d t}=I_{2}^{N}-\mu_{2}^{N} M_{2}^{N} \\
& \frac{d M_{2}^{V}}{d t}=I_{2}^{V}-\mu_{2}^{V} M_{2}^{V} \\
& \frac{d K_{1}}{d t}=\frac{k_{1} k}{\xi^{*}} M_{1} f_{1}\left(x_{1}^{1}, x_{1}^{G}, x_{1}^{N}, x_{1}^{V}\right)-\left(1-k_{1}\right) \mu_{1}^{*} K_{1}+k_{1}\left(\mu_{2, G}^{*} K_{2}^{G}+\mu_{2, N}^{*} K_{2}^{N}+\mu_{2, V}^{*} K_{2}^{V}\right) ; \\
& \frac{d K_{2}^{G}}{d t}=I_{2}^{G} p_{2}^{G} b_{2}^{G}-\mu_{2, G}^{*} K_{2}^{G} \\
& \frac{d K_{2}^{N}}{d t}=I_{2}^{N} p_{2}^{N} b_{2}^{N}-\mu_{2, N}^{*} K_{2}^{N} \\
& \frac{d K_{2}^{V}}{d t}=I_{2}^{V} p_{2}^{V} b_{2}^{V}-\mu_{2, V}^{*} K_{2}^{V} \\
& \frac{d p_{1}}{d t}=-\alpha_{1} \frac{Q_{1}}{M_{1}} p_{1} \\
& \frac{d Q_{1}}{d t}=M_{1} f_{1}\left(x_{1}^{1}, x_{1}^{G}, x_{1}^{N}, x_{1}^{V}\right)\left(1-\frac{k_{1} k}{p_{1} \xi^{*}}\right)- \\
& -\frac{k_{1}}{p_{1}}\left(\mu_{1}^{*} K_{1}+\mu_{2, G}^{*} K_{2}^{G}+\mu_{2, N}^{*} K_{2}^{N}+\mu_{2, V}^{*} K_{2}^{V}\right)-\frac{p_{2}^{G} b_{2}^{G} I_{2}^{G}+p_{2}^{V} b_{2}^{V} I_{2}^{V}+p_{2}^{N} b_{2}^{N} I_{2}^{N}}{p_{1}}- \\
& -\frac{1}{p_{1}+c^{0, G} p_{2}^{G}+c^{0, N} p_{2}^{N}+c^{0, V} p_{2}^{V}} \times \\
& \times\left(c_{0} p_{1} M_{1} f_{1}\left(x_{1}^{1}, x_{1}^{G}, x_{1}^{N}, x_{1}^{V}\right)+s \min \left\{M_{1} x_{1}^{1}, P_{0}^{A} U e^{\lambda_{p} t}\right\}\right) ; \\
& \frac{d s}{d t}=\frac{1}{\Delta} \max \left\{0, \frac{M_{1} x_{1}^{1}}{P_{0}^{A} e^{\lambda_{p} t} U}-1\right\} \\
& \frac{d p_{2}^{G}}{d t}=-\alpha_{2}\left(M_{2}^{G} f_{2}\left(\frac{V_{E}^{G}}{M_{2}^{G}}\right), M_{1} x_{1}^{G}+\frac{c^{L, G} s \min \left\{M_{1} x_{1}^{1}, P_{0}^{A} U e^{\lambda_{p} t}\right\}+c^{0, G} c^{0} p_{1} M_{1} f_{1}}{p_{1}+c^{L, G} p_{2}^{G}}\right) \times \\
& \times\left(1-\frac{M_{1} x_{1}^{G}+\frac{c^{L, G} s \min \left\{M_{1} x_{1}^{1}, P_{0}^{A} U e^{\lambda_{p} t}\right\}}{\left(p_{1}+c^{L, G} p_{2}^{G}\right)}}{M_{2}^{G} f_{2}\left(V_{E}^{G} / M_{2}^{G}\right)}+\frac{p_{2}^{g} c^{0, G} c^{0} p_{1} M_{1} f_{1}\left(x_{1}^{1}, x_{1}^{G}, x_{1}^{V}, x_{1}^{N}\right)}{M_{2}^{G} f_{2}\left(V_{E}^{G} / M_{2}^{G}\right)\left(p_{1}+c^{0, G} p_{2}^{G}\right)}\right) ; \\
& \frac{d p_{2}^{N}}{d t}=-\alpha_{2}\left(M_{2}^{N} f_{2}\left(\frac{V_{E}^{N}}{M_{2}^{N}}\right), M_{1} x_{1}^{N}+\frac{c^{L, N} s \min \left\{M_{1} x_{1}^{1}, P_{0}^{A} U e^{\lambda_{p} t}\right\}}{p_{1}+c^{L, N} p_{2}^{N}}+\frac{c^{0, N} c^{0} p_{1} M_{1} f_{1}}{p_{1}+c^{0, N} p_{2}^{N}}\right) \times \\
& \times\left(1-\frac{M_{1} x_{1}^{N}+\frac{c^{L, N} s \min \left\{M_{1} x_{1}^{1}, P_{0}^{A} U e^{\lambda} p^{t}\right\}}{p_{1}+c^{L, N} p_{2}^{N}}+\frac{c^{0, N} c^{0} p_{1} M_{1} f_{1}\left(x_{1}^{1}, x_{1}^{G}, x_{1}^{V}, x_{1}^{N}\right)}{p_{1}+c^{0, N} p_{2}^{N}}}{M_{2}^{N} f_{2}\left(\frac{V_{E}^{N}}{M_{2}^{N}}\right)}\right) p_{2}^{N} ; \\
& \frac{d p_{2}^{V}}{d t}=-\alpha_{2}\left(M_{2}^{V} f_{2}\left(\frac{V_{E}^{V}}{M_{2}^{V}}\right), M_{1} x_{1}^{V}+\frac{c^{L, V} s \min \left\{M_{1} x_{1}^{1}, P_{0}^{A} U e^{\lambda_{p} t}\right\}}{p_{1}+c^{L, V} p_{2}^{V}}+\frac{c^{0, V} c^{0} p_{1} M_{1} f_{1}}{p_{1}+c^{0, V} p_{2}^{V}}\right) \times \\
& \times\left(1-\frac{M_{1} x_{1}^{V}+\frac{c^{L, V} s \min \left\{M_{1} x_{1}^{1}, P_{0}^{A} U e^{\lambda} p^{t}\right\}}{p_{1}+c^{L, V} p_{2}^{V}}+\frac{c^{0, V} c^{0} p_{1} M_{1} f_{1}\left(x_{1}^{1}, x_{1}^{G}, x_{1}^{V}, x_{1}^{N}\right)}{p_{1}+c^{0, V} p_{2}^{V}}}{M_{2}^{V} f_{2}\left(\frac{V_{E}^{V}}{M_{2}^{V}}\right)}\right) p_{2}^{V}
\end{aligned}
$$




$$
\begin{array}{ll}
\frac{\partial f_{1}\left(x_{1}^{1}, x_{1}^{G}, x_{1}^{V}, x_{1}^{N}\right)}{\partial x_{1}^{1}}=\frac{s}{p_{1}}, & \frac{\partial f_{1}\left(x_{1}^{1}, x_{1}^{G}, x_{1}^{V}, x_{1}^{N}\right)}{\partial x_{1}^{G}}=\frac{p_{2}^{G}}{p_{1}} \\
\frac{\partial f_{1}\left(x_{1}^{1}, x_{1}^{G}, x_{1}^{V}, x_{1}^{N}\right)}{\partial x_{1}^{V}}=\frac{p_{2}^{V}}{p_{1}}, & \frac{\partial f_{1}\left(x_{1}^{1}, x_{1}^{G}, x_{1}^{V}, x_{1}^{N}\right)}{\partial x_{1}^{N}}=\frac{p_{2}^{N}}{p_{1}} .
\end{array}
$$

Since this system of nonlinear differential equations has a quite sophisticated look, it is difficult to investigate analytically its stability. In previous works [7] we have shown the stability of the solution as the results of computer simulation. It is proved that for the some set of identification parameters the solution is stable.

The identification parameters of the system model are defined: $b_{1}, b_{2}$ is the capital intensity per unit (for the first and second sector, respectively); $\mu_{1}, \mu_{2}$ is the rate of disposal capacity due to deterioration of assets; $\lambda$ is the growth rate of labour supply; $\delta$ is the time constant, which characterises the relaxation of changes in the share of investment; $p_{E}$ is the the price of energy; $\mu_{1}^{*}, \mu_{2}^{*}$ are write-off rate of production equipment; $k$ is the price of gold (or currency) in gross domestic product; $\xi^{*}$ is the provision of bank reserves; $\Delta$ is the time scale wages in the labour market; $\eta$ is the cost of gross domestic product, consumed by the owners; $c^{L}$ is the energy consumption per unit of product 1st sector; $\mu$ is the rate of disposal capacity; $r$ is the growth rate of contamination due to not new technology. In addition, we consider the moment of time $\tau$ of creation a new production unit; $\nu(t)$ used new technology, that is the lowest cost of living labour per unit of output; the smallest release of pollutants $s(t)$ per unit of material production.

For constructing ecological and economical production function we assume that the growth rate of labour productivity due to technological innovations generated $-\frac{1}{\nu} \frac{d \nu}{d t}$ is proportional to share of the total new capacity $I(t)$ in power, i.e. $\frac{1}{\nu} \frac{d \nu}{d t}=-\varepsilon_{1} \sigma(t)$, and the rate of emissions reduction due to technological innovation is also proportional share of new capacity created, i.e. $\frac{1}{s} \frac{d s}{d t}=-\varepsilon_{2} \sigma(t)[10]$.

Then ecological and economic production function takes the form

$$
\begin{aligned}
& f\left(t, x_{1}, x_{2}\right)=1-e^{-\int_{t-\theta}^{t} \sigma(k) d k}, \\
& \left(1-\varepsilon_{1}\right) x_{1} \equiv \mu \nu(t) \int_{t-\theta}^{t} e^{\mu(t-\tau)-\int_{\tau}^{t} \sigma(k) d k} d \tau+\nu(t)\left(1-e^{\mu \theta-\left(1-\varepsilon_{1}\right)} \int_{t-\theta}^{t} \sigma(k) d k\right),
\end{aligned}
$$

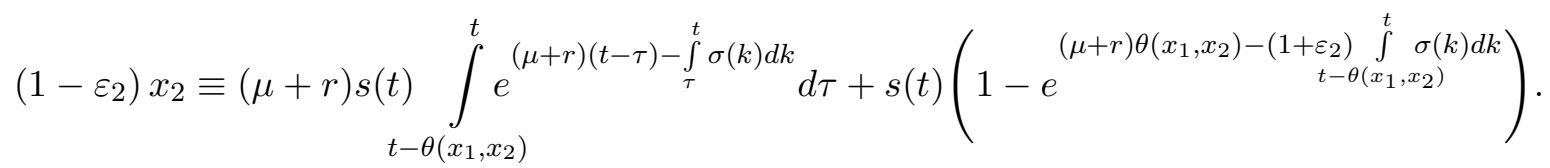

From the total submission of production function the expressions for the production function in several partial cases can be obtained. Analytical expression for production function $f\left(t, x_{1}, x_{2}\right)$ splits into two cases: the dependence of the material issue from labour costs $f_{1}\left(t, x_{1}\right)$ and the dependence of the material release from the established environmental constraints $f_{2}\left(t, x_{2}\right)$. The connection between them is below:

$$
f\left(t, x_{1}, x_{2}\right)=\min \left\{f_{1}\left(t, x_{1}\right), f_{2}\left(t, x_{2}\right)\right\} .
$$

1. If the power does not frazzle $\mu=0$, and the growth rate of contamination due to aging technology $r=0$, then

$$
\begin{gathered}
f_{1}\left(t, x_{1}\right)=1-\left(1-\frac{1-\varepsilon_{1}}{\nu(t)} x_{1}\right)^{\frac{1}{1-\varepsilon_{1}}} \quad \text { if } \quad x_{1} \leqslant \frac{\nu(t)}{1-\varepsilon_{1}} \\
f_{1}\left(t, x_{1}\right) \equiv 1 \quad \text { if } \quad x_{1}>\frac{\nu(t)}{1-\varepsilon_{1}}
\end{gathered}
$$




$$
\begin{gathered}
f_{2}\left(t, x_{2}\right)=1-\left(1-\frac{1-\varepsilon_{2}}{s(t)} x_{2}\right)^{\frac{1}{1-\varepsilon_{2}}} \quad \text { if } \quad x_{2} \leqslant \frac{s(t)}{1-\varepsilon_{2}} \\
f_{2}\left(t, x_{2}\right) \equiv 1 \quad \text { if } \quad x_{2}>\frac{s(t)}{1-\varepsilon_{2}} .
\end{gathered}
$$

2. If investments $I(t)$ are constant share of facilities $M(t)$, i.e., $\sigma(t)=$ const then

$$
\begin{gathered}
f_{1}\left(t, x_{1}\right)=1-\left(1-\frac{1-\varepsilon_{1}-\frac{\mu}{\sigma}}{\nu(t)} x_{1}\right)^{\frac{1}{1-\varepsilon_{1}-\frac{\mu}{\sigma}}} \quad \text { if } \quad x_{1} \leqslant \frac{\nu(t)}{1-\varepsilon_{1}-\frac{\mu}{\sigma}} ; \\
f_{1}\left(t, x_{1}\right) \equiv 1 \quad \text { if } \quad x_{1}>\frac{\nu(t)}{1-\varepsilon_{1}-\frac{\mu}{\sigma}} ; \\
f_{2}\left(t, x_{2}\right)=1-\left(1-\frac{1-\varepsilon_{2}-\frac{\mu+r}{\sigma}}{s(t)} x_{2}\right)^{\frac{1}{1-\varepsilon_{2}-\frac{\mu+r}{\sigma}}} \quad \text { if } \quad x_{2} \leqslant \frac{s(t)}{1+\varepsilon_{2}-\frac{\mu+r}{\sigma}} ; \\
f_{2}\left(t, x_{2}\right) \equiv 1 \quad \text { if } \quad x_{2}>\frac{s(t)}{1+\varepsilon_{2}-\frac{\mu+r}{\sigma}} .
\end{gathered}
$$

3. If $\sigma=$ const, and no technological innovations $\left(\varepsilon_{1}=0, \varepsilon_{2}=0\right)$, then

$$
\begin{aligned}
& f_{1}\left(t, x_{1}\right)=1-\left(1-\frac{1-\frac{\mu+r}{\sigma}}{\nu(t)} x_{1}\right)^{\frac{1}{1-\frac{\mu+r}{\sigma}}} \quad \text { if } \quad x_{1} \leqslant \frac{\nu(t)}{1-\frac{\mu+r}{\sigma}} \\
& f_{1}\left(t, x_{1}\right) \equiv 1 \quad \text { if } \quad x_{1}>\frac{\nu(t)}{1-\frac{\mu+r}{\sigma}} ; \\
& f_{2}\left(t, x_{2}\right)=1-\left(1-\frac{1-\frac{\mu+r}{\sigma}}{s(t)} x_{2}\right)^{\frac{1}{1-\frac{\mu+r}{\sigma}}} \quad \text { if } \quad x_{2} \leqslant \frac{s(t)}{1-\frac{\mu+r}{\sigma}} \\
& f\left(t, x_{2}\right) \equiv 1 \quad \text { if } \quad x_{2}>\frac{s(t)}{1-\frac{\mu+r}{\sigma}} .
\end{aligned}
$$

Conclusions and further researches directions. In this article we have investigated the problem of constructing ecological and economical production function for energy dependent economics, which can be modelled by systems of partial differential equations. Some types of production functions are shown for practical use. After parameters being determined and the corresponding production function built, this system model allows someone to build the system of forecasts, to make certain assumptions about the economy over time, check the results of the theory in the system, not in the real economy (use simulation modelling).

[1] Hritonenko N., Yatsenko Y. Mathematical modelling in economics, ecology and the environment series. Springer Optimization and Its Applications, Vol.88 (2013).

[2] McConnell C., Brue S., Flynn S. Macroeconomics / Edition 19. McGraw-Hill Higher Education (2011).

[3] Ponomarenko K. A. The basis of economical cybernetics. Kyiv: KNTEU, (2002), (in Ukrainian).

[4] Petrov A. A. Pospelov I. G., Shananin A. A. Experience in mathematical modelling of ecomonics. Moscow: "Energoizdat" (1996), (in Russian).

[5] Blyth W. The economics of transition in the power sector. International Energy Agency (2009).

[6] Kostrobii P. P., Gaiduchok O. V. Mathematical modelling of energy dependent economics. Phys.-math. modelling and inform. techn. Vol.19, 92-103 (2014), (in Ukrainian). 
[7] Gaiduchok O. Results of energy dependent economics numerical simulation. Khmelnytskyi: Bulletin of KNU "Economic science". N.1, vol.1, 184-186 (2009), (in Ukrainian).

[8] Gaiduchok O. System forecasting for two sector economics. Donetsk: "Economics: Problem of science and practise". N.230, vol.II, 495-510 (2010), (in Ukrainian).

[9] Kaltenbacher B. Parameter identification in partial differential equations. University of Linz (2005).

[10] Onyschenko A. "Construction of ecological and economical production function by the way of aggregating technology microlisting. Kyiv: Economic Bulletin NTUU "KPI", N.8, 485-490 (2011), (in Ukrainian).

\title{
Побудова еколого-економічної виробничої функції для енергозалежної економіки
}

\author{
Дячок В. В., Гайдучок О. В. \\ Національний університет «Львівсъка політехніка» \\ вул. С. Бандери, 12, 79013, Львів, Україна
}

\begin{abstract}
Описано системну модель двосекторної економіки, із виокремленням виробничого та енергетичного секторів. У виробництві виділено два сектори - перший сектор виробляє кінцевий продукт, а другий сектор - енергію, необхідну для виробництва кінцевого продукту. Записано моделі виробництва для секторів. Отримано системну модель такої економіки як систему диференціальних рівнянь. Показано параметричне представлення еколого-економічної виробничої функції на підставі розподілу виробничих потужностей по технологіях.
\end{abstract}

Ключові слова: системна модель двосекторної економіки, еколого-економічне моделювання, еколого-економічна виробнича функція

2000 MSC: 93C23, 49K20

УдК: 519.86 